\title{
INNOVATIVE TECHNOLOGIES IN MODERN CULTURAL EDUCATION
}

\section{Yepyk L. I., Kovalenko O. V.}

\section{INTRODUCTION}

Contemporary Ukrainian higher education faces the problem of choosing the means and methods of study that would enable each student not only to acquire knowledge and skills, but also stimulate selfimprovement, intellectual growth, create such an educational environment that would absolutely contribute to the desire of every young person to get knowledge and realize his educational requirements.

Ukrainian higher education should become such an environment where the teacher will cease to be a mentor and a controller of students, but rather, a consultant and a transmitter of his or her own experience, a partner in solving theoretical and practical problems.

Postindustrial society encourages independently minded people who would be able to self-realisation based on their knowledge, skills and subjective self-assessment.

American economist Lester Thurow predicts that, despite the advancement of technology and artificial intelligence, it will require long-term public investment in research, development, education and infrastructure ${ }^{1}$.

Recognizing this, more and more students of higher educational establishments are in need of changes in the system of learning and teaching in the direction of mastering their knowledge, practical and intellectual skills they need to assert themselves, to realize themselves in this life.

A modern student who has made a conscious choice of profession is not a passive subject of the educational process.

Students become the initiators of changes in teaching and learning methods, so abstract-oriented student-centered technologies do not work and do not produce the expected results. It is possible to teach everyone,

1 Лестер К. Туроу. Будущее капитализма. Главы 1-7. URL : http://modernproblems.org.ru/capital/89-thurow.html (дата звернення: 24.02.2020). 
to discover the potential of all thanks to personally oriented technologies, to establish real cooperation between the teacher and the student .

\section{Contemporary cultural axis: theoretical aspect}

Modern education is decisive for economic growth and the basis for shaping future social opportunities ${ }^{2}$. A modern culturologist must be a highly qualified specialist, capable to work effectively in the specialty and competitive in the labor market, that is, competent in their subject area.

Educational and professional program of bachelor's degree in the specialty 034 "Cultural Studies" defines the integral competence of the future cultural scientist as:

1) the ability to provide an adequate assessment of the current state for cultural and artistic life, social and economic realities of the studied phenomenon or process, to make sound decisions concerning the requests of the population;

2) to demonstrate effective interpersonal communication and to improve constantly the emotional abilities of future professionals in communication skills at the individual, interpersonal and collective levels;

3) to demonstrate initiative and enterprising in the fields of culture and the arts as well as in industrial production and social life; keeping ethical principles of behavior and awareness of social responsibility for the results of their work in the future professional activity ${ }^{3}$.

Focus on professional educational program is made on acquiring skills and knowledge in Applied Cultural Studies, which provide definite time and the possibility of further education and career growth. The program determines the specific involvement of Bachelor of Cultural Studies at the local, regional and national levels.

Taking into account the needs of the modern labor market, professional competences have also been identified, which should be formed during four years of training and practical activity.

The Bachelor of Cultural Studies should have a:

${ }^{2}$ Нейматов Я.М. Образование в XXI веке: тенденции и прогнозы. Москва : Алгоритм, 2002. 480 с. С. 13.

3 Освітньо-професійна програма «Культурологія» першого рівня вищої освіти (за спеціальністю 034 Культурологія галузі знань 03 Гуманітарні науки). Суми, 2018. 15 с. С. 6. 
1) degree of implementation of cultural projects based on the discovery of the laws and principles of artistic creativity;

2) the usefulness of exercise under the supervision of professional functions in the field called bonds with the public in government, civil society, businesses, the media, the social sphere, in politics, economy, science, culture and sport;

3) the ability to use effectively theoretical knowledge and heritage of the world art practice in the process of socio-cultural activities;

4) to possess knowledge and skills to work in the press center, the press service, the press department, media department on connections with public, Center for Public, departments of the advertisement, communication agencies is the ability to form a system of knowledge about the content and features of major cultural and art.

As for the practice, the Bachelor of Cultural Studies must be able:

- to implement cultural projects by identifying laws and principles of art;

- keeping under the control professional functions in the field called bonds with the public in government, civil society, businesses, media, social sphere, in politics, economy, science, culture, sport;

- efficiently use theoretical knowledge and heritage of world art practices in the implementation of socio-cultural activities;

- work in the press center, the press service, the press department, media department called connections with public, Center for Public departments of advertising, communication agencies;

- have basic knowledge of planning and implementing communication campaigns and activities, use controlled methods and techniques opinion polls;

- have the basics of professional communication, rules of etiquette and dialogue and methods of influence.

Modern cultural scientist should be able to form a holistic view of the world art culture, taking into account the national specificity of any ethno-cultural formation, including the culture of Ukraine, and the principles of state policy in the field of culture and art, have basic skills of creating texts used in the field of communication with the public, have skills of literature editing, copywriting, basic skills in media planning, basic communication skills, ability to establish, maintain and develop interpersonal relationships, business relationships with various governmental, financial, social structures, media information, advertising agencies, discuss professional problems, defend their point of view, 
explain the essence of phenomena, events, processes, draw conclusions, provide reasoned answers.

Bachelor of cultural studies should have developed skills of organizational work, development of cultural projects, preparation of exhibitions, art programs, public relations campaigns, creation of the script of programs of socio-cultural events, etc., skills of self-education and self-bringing-up and continuous improvement of professional skill ${ }^{4}$.

That is why improving the quality of training of cultural specialists becomes a high priority for higher education, which requires the improvement of forms, methods and technologies for the organization of the educational process and, of course, the introduction of innovative teaching technologies.

N. Artikutsa, I. Dychkivska, O. Dubaseniuk, L. Danilenko, M. Clarin, N. Kuzmina, V. Palamarchuk, O. Pehota, O. Semenog, S. Sysoeva, V. Slastoni and others were engaged in research of the problems of pedagogical innovation, studying and introduction the innovative technologies.

The piculiarities of the communicative approach were made by N. Borysko, A. Bodalev, J. Winter, W. Kan- Kalyk, S. Karaman, G. Kitaygorodskaya, L. Lisak, A. Leontyev, V. Mikhailyuk, S. Nikolayeva, O. Pavlenko, T. Symonenko, N. Totska, Y. Fedorenko and others.

The Encyclopedia of Education (2008), defines innovation in education as a process of creating, implementing and disseminating new ideas, tools, pedagogical and management technologies in educational practice, which in turn raises the indicators (levels) of achievement of structural components of education and the transitions of the system into a qualitatively new state is held.

The word "innovation" is ambiguous because it consists of two forms: just the idea itself and the process of its practical implementation ${ }^{5}$.

The innovative education should be oriented to the dynamic changes in the world and society, offering training activity, based on effective techniques that primarily focused on the development of various forms

4 Освітньо-професійна програма «Культурологія» першого рівня вищої освіти (за спеціальністю 034 Культурологія галузі знань 03 Гуманітарні науки). Суми, 2018. 15 с. С. 6.

5 Енциклопедія освіти / Акад. пед. наук України; гол.ред. В.Г. Кремень. Київ : Юрінком Інтер, 2008. 1040 с. С. 338-340. 
of thinking, considering creativity and social adaptive capacity of the individual ${ }^{6}$.

In our opinion, innovative teaching technologies are the most effective psychological and pedagogical methods, forms, tools based on the cultural and educational aspect, traditional educational achievements of the society, which have education and educational effects, but may change depending on time, psychological and age peculiarities of a personality and chosen specialty.

These technologies are introduced into the educational process of a higher education institution for the acquisition of knowledge, development of skills to work in the profession after graduation and are important for the daily life of a specialist in cultural studies.

In fact, innovative learning technologies form an educated specialist with theoretical knowledge and practical skills and an understanding of the need for education and self-improvement over a lifetime.

Today, in our opinion, effective innovative methods in the system of training specialists in cultural studies should be:

1) interactive forms of training (business and role games, solving problem situations, case studies, discussions);

2) problem-oriented and situational approach to learning;

3) creation of active forms of cooperation with employers and involvement of students in the implementation of research projects "on request" and for the needs of the employer ${ }^{7}$;

4) creation of conditions for creative work of students, assistance and stimulation of individual and independent educational activity;

5) development of theoretical methods and practical cases in order to create an effective dialogue between a teacher and a student, a student and a teacher, a student and a team;

6) taking into account the tendencies of development of the environment of the labor market and the market of educational services when creating and changing curricula, plans for training and retraining of personnel;

6 Дичківська I. М. Інноваційні педагогічні технології: навчальний посібник. Київ : Академвидав, 2004. 352 с. С. 339.

7 Освітньо-професійна програма «Культурологія» першого рівня вищої освіти (за спеціальністю 034 Культурологія галузі знань 03 Гуманітарні науки). Суми, 2018. 15 с. С. 3. 
7) active use of modern information and communication technologies (organization of web conferences, webinars, creation of virtual teams working on the projects, the Internet forums);

8) the transition to a system of training, which aims not to accumulate a set of knowledge, but to develop the ability to think analytically and to evaluate the information critically;

9) orientation to formation of skills of self-organization, selfpreparation, self-training;

According to scientists, the complex of such measures will allow to train specialists in demand at the labor market ${ }^{8}$.

The use of innovative technologies shall be designed to create a specific environment, providing student-centered education, outputoriented study prog-ramme, competency approach in building and implementing curricula (competence-based approach), training focused on results (result-based education) ${ }^{9}$.

The educational process is accompanied by the solution of a number of tasks, among which - the search for student motivation for learning, the creation of a positive emotional environment between the teacher and the students, ensuring the required level of students success and the realization of their creative potential.

Student-centered education using innovative technology makes possible the teacher to decide both educational and psychological problems.

The first stage of cooperation in the learning process begins with the introduction of the student with syllabus curriculum, and then the teacher himself.

At this stage, the initial positive impression of the teacher should be formed first. To do this, the teacher must not only provide information about the subject, the peculiarities of its study, types of student's work and its assessment, but also to show their maximum interest in the educational achievements of each student, a willingness to help in solving educational problems.

${ }^{8}$ Пригара О.Ю. Інновації в науці та освіті: виклики сучасності. Інновації в науці та освіті: виклики сучасності. Збірник наукових есе учасників стажування для освітян. Варшава, Республіка Польща 2018. 209 с. С. 14-17.

9 Стандарти і рекомендації щодо забезпечення якості в Європейському просторі вищої освіти (ESG). Київ : ТОВ «ЦС», 2015. 32 с. С. 15. 
Our experience shows that in the study of each subject it is desirable to provide students with information about its practical application, or to provide cases from their own experience.

It inspires the confidence of the student team, adds bonuses to the teacher as a practician, sets students up to study the discipline.

When it comes to the discipline for a choice, then students motivation is higher because they choose subjects that match their inner preferences.

Most students are interested in the number of points received for certain types of educational activities, and today it is possible to do not only during lectures or practical classes, but also by doing independent work.

We provide students with developed assignments for self-study, emphasizing that in this case, the number of points obtained depends on the fulfillment of all conditions for independent work.

Depending on the subject and the course requirements to perform the tasks are different.

We gradually accustom our freshmen to independent work, hold consultations and trainings if it is necessary. The motivation for independent work is, of course, assessment, but also the acquisition, consolidation of knowledge, the opportunity to show a non-standard creative approach are important.

All tasks have a clear content, written means and methods of execution, current and final deadlines (if the task is large) and determined number of points for successful completion.

Independent work of students of cultural studies is based both on the study of additional issues in the disciplines and the preparation of mini projects, educational presentations, popular science lectures for students, speaking at forums/conferences, writing posts for social networks, writing essays, making up excursions, etc.

In our opinion, independent work should complete and illustrate the teaching material of lectures or practical classes.

For correct work on independent tasks, the teacher and the student should be clearly aware of all stages of the task, methods and forms of implementation, results and evaluation criteria.

Usually independent work is divided into the following stages:

1. Goal setting. The purpose of the work is determined taking into account the wishes of students to consolidate, summarize the acquired theoretical knowledge.

2. Planning the number of assignments per semester or per year. During the discussion of the curriculum, the teacher identifies the key 
competencies that should be formed in the student after mastering a certain discipline. Depending on this, tasks for independent work are formed .

3. Discussion (prescribing) requirements for the task and determining the methods and forms of its implementation.

The tasks and methods of its implementation should be clear to all students. If students are willing to split into micro-groups to perform a job, or perform it together with another academic group, this is welcomed, but the criteria for evaluating each activity are discussed further.

We always determine the forms of submission of finished work, writing, presentation and amount of finished work.

We invite students to discuss their own work in the form of a round table, to share their impressions of cooperation, to comment on the successful and difficult moments. This moment adds responsibility for the quality of the work performed.

4. The order of points for work.

It is one of the most important moments in the work of the teacher and cooperation with the student team.

The assessment should reflect real involvement in the work and, at the same time, provide an incentive for further work.

We always carefully develop criteria for evaluating independent work and for some tasks, depending on the specifics, usually some criteria are modified and supplemented.

To build mutual trust as a basis for learning and cooperation, we use the method of self-assessment and evaluation of other students work. It forms subjective attitude of the students both to their own efforts and the work of classmates.

\section{Interactive.}

This stage is present throughout the process of independent work of a students. They are personal or group consultations with the teacher, discussion of intermediate achievements and, lastly, protection or discussion of the results of work, presentation of receiveded points.

We do not help to do, we direct work, we advise the best methods for its performance, just to understand our teaching role noadays.

The innovativeness of the student-centered approach to learning is that it focuses on critical analytical learning and understanding, increased responsibility and accountability of the student and increasing his autonomy. 
Moving a student's personality into the center of the process requires many factors to change, including the type of student-teacher relationship that changes its role and becomes a referent personality for the student ${ }^{10}$.

\section{Case studies in the process of preparation of cultural specialists}

In the context of globalization, accompanied by the unification of spiritual processes, the problem of improving the quality of cultural education is urgent.

Organization of social and cultural processes in the Ukrainian society is one of the components of the work of cultural scientists and is aimed at meeting the needs of people in cultural development, self-development and creativity ${ }^{11}$.

Of course, in such a situation, the personality of the culturologist, his level of theoretical background and practical experience are of paramount importance, which is now expressed in the category of "professional competence".

One of the definitions of this concept is the understanding of competence as a specialist, based on theoretical knowledge, skills, means of activity and value - essential orientations, unity of cognitive and activity components, socio-cultural, personal characteristics and experience.

Professional competence reflects the spiritual and intellectual potential of a specialist and the ability to use it while solving practical problems.

The educational and professional training program of Bachelor of Cultural Studies is aimed at mastering fundamental practical knowledge and research skills in the field of cultural studies.

It is oriented on professionally trained assistants for culture, professionals connected with public capable of implementing their theoretical and practical knowledge in professional activities. The programme takes into account new requirements called connection between theory and practice.

${ }^{10}$ Кудрявцева Т. К. Студентоцентроване навчання як сучасна парадигма вищої освіти. URL : http://college.nuph.edu.ua/wp-content/uploads/2018/01/ Kudriavtseva_pedagog-chyt-2018.pdf (дата звернення 24.02.2020).

11 Тестов В.А. Информационное общество: переход к новой парадигме образования. Педагогика. 2012. № 4. С. 6. 
It forms specialists with a new perspective way of thinking, able not only to apply the acquired knowledge, but also to generate new ideas based on the modern achievements of the world and Ukrainian culture.

To form the professional competence of future culturologists, we use intensive forms of training, interactive methods that maximize the learning process - training, game design, brainstorming, discussions, monitoring, case studies and others.

The content of the active learning is that the educational process is organized so that all its participants are involved in its implementation, gaining both educational and collaborative experience.

In the process of interactive learning, the teacher concedes his active position in favor of the students. The role of the teacher is to create the conditions for students' initiative.

The use of interactive teaching methods includes models of life situations, the use of role-playing, business games, trainings, case-study (analysis of specific and practical situations), the creation of educational projects, educational discussions and more ${ }^{12}$.

The essence of the method of cases is the independent work of future culturologists in a specially created professional situation, which allows to combine theoretical training and practical skills for future professional activity.

We offer students to discuss some specific professional situation during the lectures and workshops, stressing that the long-lasting knowledge is the one derived from their own reflection and conclusions.

The case can be used in a group with a single problem area, it not only saves time, but also provides students with interesting social information, to think deeply about it, to understand, to discuss, to share impressions, to discuss and to gain a positive learning experience.

Introducing the case-study method, the teacher should make up a creative learning environment, during which the search for truth in a specific practical situation is important and this maximizes the student's creative abilities, his creative thinking, increases responsibility for decisions, learns to work in a team, leads to a discussion and argues his point of view, he teaches to perform his professional functions in the society as effectively as it is possible.

\footnotetext{
Новолодская С.Л. Синергетический подход к исследовани педагогических проблем в поликультурном образовании. Инноващии в образовании. 2012. № 1. С. 66.
} 
The complexity, clarity and integrability of the case method is shown in the table $1^{13}$.

Table 1

\begin{tabular}{|c|c|}
\hline $\begin{array}{l}\text { Method integrated into } \\
\text { the case method }\end{array}$ & $\begin{array}{l}\text { Characterization of its role } \\
\text { in the case method }\end{array}$ \\
\hline Modeling & Building a situation model \\
\hline System analysis & System views in the situation \\
\hline A thought experiment & analysis \\
\hline & A means of gaining knowledge of a \\
\hline Descriptive method & situation by imagining it \\
\hline The problematic method & Creating a situation description \\
\hline & Presentation of the problem, which \\
\hline Method of classification & is the basis of the situation \\
\hline Game methods & Creating ordered lists, properties, \\
\hline A powerful attack & $\begin{array}{l}\text { parties, which is the basis of the } \\
\text { situation }\end{array}$ \\
\hline Discussion & Identifying options for behavior \\
\hline & Generate ideas about the situation \\
\hline & $\begin{array}{l}\text { Exchange of views on the problem } \\
\text { and ways to solve it }\end{array}$ \\
\hline
\end{tabular}

Case study as a method of teaching promotes the formation of students ability to solve certain problems, first in similar and then in nonstandard specific socio-cultural situations.

We select and review case studies that are typical for the work of a culturologist, and use them both during work in the audience and directly in practice, focused on the effective solution of specific socio-cultural problems.

Of course, in the pedagogical educational process, the didactic, educational, developmental and civilizational goals of the case should be clearly spelled out and formulated on the basis of the teaching material that students are studying.

Those decisions that students make while developing the case are harmoniously included into the formation of knowledge, skills and aptitudes, through which they learn the means of cultural activities. Case may illustrate a theoretical or practical situation, and may be also a

13 Хуторской А.В. Педагогическая инноватика : учеб. пособие для студентов высш. учеб. заведений. Москва, 2008. 256 с. С. 34. 
combination of both. Each case has its own structure, purpose, tasks and the ways of solving.

Taking into account the peculiarities of the training of modern cultural practitioners, as an additional tool in the development of cases, we use the method "man-monitor", which we offer students in the study of such disciplines as "Applied Cultural", "Public Relations" and others.

We use this method actively, involving students to participate in real cultural practices that become the basis of their professional experience.

Let's take a look at some of the cases we use while studying disciplines with cultural students.

\section{Case Study 1 - "Applied Cultural” discipline.}

Identify the purpose, objectives, methods of organization of the Open Door Day of the Culture and Arts Department.

This case is based on the real-world experience of all participants in the learning process, because they were present in one way or another at the real event or at similar events. Teacher experience is an organizer, student experience is observers, or active participants.

Based on the theoretical knowledge acquired during the study of the discipline "Applied Cultural" students discuss tasks, share their experiences and impressions, express opinions about the quality of the activities or an activity they see.

As some general conclusions are formulated, the teacher directs the discussion toward the question "what needs to be changed or improved during such an event?". The point is that the theoretical knowledge and experience gained as a "man-monitor" should be of real value and realization. Students who make suggestions about changing the format of the event, its content load, argue their position with their own observations, experience from others and similar events.

This case does not have a specific solution, however, all the suggestions of the teacher/students are clearly recorded and submitted for further analysis on the independent work of the group. While working on the case, the teacher emphasizes that each student's opinion, their vision of the situation are important for working together.

\section{Case 2 - discipline "Public relations".}

It means to develop the principles of an information campaign to promote the specialty "Cultural Studies".

This case is based on the own experiences and realities of the faculty, but has no definitive completion. Students of cultural studies on the basis of their knowledge, experience of the entrance campaign, monitoring of 
social networks conduct analysis of the most effective methods of information companies.

Work on the case is carried out by the whole group or we divide students into micro-groups with different tasks. We provide this case as an independent work, breaking it down into separate tasks that we discuss whereas we complete it.

An additional aspect of this activity is to create a promo-video of specialty "cultural relationship" and presenting it to social networks.

The peculiarity of this case study is that the relative majority of students is actively involved in the work through their choices of a direct training, in the interest to work in the social networks, the ability to show creativity while creating promo-video.

\section{Case 3 - discipline "Fundamentals of excursion and museum activity".}

It means to develop theoretical foundations of virtual tour of the institution. It is quite a difficult task and it requires a long time and thorough reflection.

The assignment is given for students to work independently, but with defined deadlines for the completion of separate stages.

Case has a theoretical part, which provides a generalization of knowledge about the methods of creating excursions, the basics of information campaigns, determining the purpose, objectives and results of work.

This part of the case is carried out for the whole group, further, depending on the defined directions of work, microgroups work in their directions. It should be noted that teachers bring their vision to the solution of individual questions of the case, without insisting on taking them as a basis.

In order to activate students creative potential, additional (between deadlines) discussions are held on ideas, developments that involve both students and individual micro groups.

To maintain an interactive connection between the participants of the educational process we periodically (once a semester - writing, three times a semester - oral) conduct a survey among students about learning, including the use case - method.

Oral surveys are taken in the form of a free exchange of views, summarization of available experiences, reflection on the acquired skills and wishes for further educational activities. 
Students during the debate offer their own case studies, prepared in advance, in order to address and get one/several variants of solution the problem.

To conduct a written survey, we have developed a series of questions that students deal with anonymously (according to the wish), expressing their honesty about the case study method or other teaching methods that they are offered.

We make up the following questions:

1. Do you consider the case study necessary, interesting, useful for the formation of aptitudes, skills for practical activity of a modern cultural scientist?

2. Does the case method contribute to the formation of creative thinking?

3. Does the case-method activate cognitive activity, teache to make decisions, form the ability to draw up an action plan from idea to project implementation?

4. Does the case method form the ability to work in a team?

5. Which cases have you considered to be the most powerful from the educational and practical point of view?

Analyzing the students answers, we can conclude that the case-stage is one of the most effective interactive methods, because, in their opinions, it creates a real opportunity to think creatively and put into practice educational theoretical material, to solve standard and extraordinary problems in the cultural sphere, to accept creative decisions, work as a team and learn to take responsibility for the execution of certain types of work, or all project as a whole, which is a manifestation not only of a creative but also of a formed personality.

\section{CONCLUSIONS}

The post-industrial information society requires qualitative changes in the quality of education, including cultural education.

The field of culture needs creative, thinking, theoretically and practically trained specialists, ready to solve problems of varying degree of complexity, take responsibility for the made decisions, cooperate in a team, find solutions to the problem quickly and qualitatively.

Given that the Bachelor of Cultural Studies specialization is media culture, the creation and management of social and cultural projects, the establishment of social communications, the practical component of training which should be at a high level. 
That is why we prefer and emphasize interactive teaching methods for students of cultural studies, which will allow us to form a key competence that would contribute to the achievement of life success and correspond to diverse spheres of life $\mathrm{e}^{14}$.

The key competence of the modern cultural student is a subjective category that captures the socially recognized set of knowledge, skills, attitudes of a certain level, which are used in a broad range of human activities. It is the ability of a person to perform a complex multifunctional, multi-objective, culturally appropriate activities, effectively solving the relevant problems.

Key competencies are integral characteristics of quality training of the objects of study, related to their ability to target meaningful use of complex knowledge, skills, attitudes on interdisciplinary range of problems.

The main features of vital (key) competencies are:

1. Multifunctionality (it allows to solve various problems in different spheres of personal and public life).

2. Supersubjectiveness and interdisciplanarity (can be used not only at school but also at work, in a family, in the political sphere, etc.).

3. Multidimensionality (includes knowledge, thought processes, intellectual, educational and practical skills, creative discoveries, strategies, technologies, procedures, emotions, evaluations, etc.).

4. Provide a broad sphere of personality development (its logical, creative and critical thinking, self-reflection, self-determination, selfesteem, self-education, etc. $)^{15}$.

The use of the case-study method enhances the practical component of cultural education, contributes to its development and improvement.

It should be noted that the case-study requires from a teacher knowledge of modern teaching methods, the ability to apply them in practice, flexible creative approach to the choice of means of carrying out the educational process, based on the goal, the characteristics of the student team, the implementation of learning tasks and expected results.

As for the case of study, the involvement of the teacher in the implementation of cultural projects, the availability of real experience in

14 Стратегія реформування освіти в Україні: Рекомендації 3 освітньої політики. Київ : К.І.С., 2003. 296 с. С. 20.

15 Приходько В.М. Моніторинг якості освітньої діяльності загальноосвітнього навчального закладу: педагогічні основи й управлінський аспект : монографія. Запоріжжя, 2011. 460 с. С. 232. 
organizing and conducting, for example, cultural, political, social events is of tremendous importance in creating and solving the case.

\section{SUMMARY}

The authors of the study analyze current requirements for the training of specialists in the field of cultural studies. There are some requirements for the integral and professional competence of a modern specialist in cultural studies at work. The paper analyzes the problem of students independent work as the basis of student-centered learning. An algorithm is proposed for organizing students independent work. The role of the teacher in the training of specialists in cultural studies is analyzed. The authors prove that through the use of innovative technologies for teaching cultural disciplines, the organization of student-centered learning allows for motivated learning, high theoretical knowledge and practical skills of students. The authors give examples of their own case studies used in the teaching of cultural disciplines.

\section{REFERENCES}

1. Лестер К. Туроу. Будущее капитализма. Главы 1-7. URL : http://modernproblems.org.ru/capital/89-thurow.html (дата звернення: 24.02.2020).

2. Нейматов Я.М. Образование в XXI веке: тенденции и прогнозы. Москва : Алгоритм, 2002. 480 с. С. 13.

3. Освітньо-професійна програма «Культурологія» першого рівня вищої освіти (за спеціальністю 034 Культурологія галузі знань 03 Гуманітарні науки). Суми, 2018. 15 с. С. 6.

4. Освітньо-професійна програма «Культурологія» першого рівня вищої освіти (за спеціальністю 034 Культурологія галузі знань 03 Гуманітарні науки). Суми, 2018. 15 с. С. 6-7.

5. Енциклопедія освіти / Акад. пед. наук України ; гол.ред. В.Г. Кремень. Київ : Юрінком Інтер, 2008. 1040 с. С. 338-340.

6. Дичківська I.M. Інноваційні педагогічні технології: навчальний посібник. Київ : Академвидав, 2004. 352 с. С. 339.

7. Освітньо-професійна програма «Культурологія» першого рівня вищої освіти (за спеціальністю 034 Культурологія галузі знань 03 Гуманітарні науки). Суми, 2018. 15 с. С. 3.

8. Пригара О.Ю. Інновації в науці та освіті: виклики сучасності. Інновачії в науці та освіті: виклики сучасності. Збірник наукових есе учасників стажування для освітян. Варшава, Республіка Польща 2018. 209 c. C. 14-17. 
9. Стандарти i рекомендації щодо забезпечення якості в Європейському просторі вищої освіти (ESG). Київ : ТОВ «ЦС», 2015. 32 с. С. 15.

10. Кудрявцева Т. К. Студентоцентроване навчання як сучасна парадигма вищої освіти. URL : http://college.nuph.edu.ua/wpcontent/uploads/2018/01/ Kudriavtseva_pedagog-chyt-2018.pdf (дата звернення: 24.02.2020).

11. Тестов В.А. Информационное общество: переход к новой парадигме образования. Педагогика. 2012. № 4. С. 6.

12. Новолодская С.Л. Синергетический подход к исследовани педагогических проблем в поликультурном образовании. Инновации в образовании. 2012. № 1. С. 60-72. С. 66.

13. Хуторской А.В. Педагогическая инноватика : учеб. пособие для студентов высш. учеб. заведений. Москва, 2008. 256 с. С. 34.

14. Стратегія реформування освіти в Україні: Рекомендації 3 освітньої політики. Киъв : К.І.С., 2003. 296 с. С. 20.

15. Приходько В.М. Моніторинг якості освітньої діяльності загальноосвітнього навчального закладу: педагогічні основи й управлінський аспект: монографія. Запоріжжя, 2011. 460 с. С. 232.

\section{Information about authors:} Yepyk L. I.,

Candidate of Historical Sciences, Associate Professor at the Department of Fine Arts, Musicology and Cultural Studies Sumy State A. S. Makarenko Pedagogical University 87, Romenska Str., Sumy, Ukraine

Kovalenko O. V., Candidate of Pedagogical Sciences, Associate Professor at the Department of Fine Arts, Musicology and Cultural Studies Sumy State A. S. Makarenko Pedagogical University 87, Romenska Str., Sumy, Ukraine 